\title{
ORIGIN OF THE STATE STATISTICAL SERVICE IN CZECHO-SLOVAKIA
}

\author{
PROKOP ZÁVODSKÝa, ${ }^{*}$, ONDŘEJ ŠIMPACH ${ }^{\mathrm{a}}$ \\ prokop.zavodsky@vse.cz,ondrej.simpach@vse.cz \\ a University of Economics in Prague, Faculty of Informatics and Statistics, Department of Statistics and \\ Probability, W. Churchill Sq. 4, Prague, Czech Republic
}

\begin{abstract}
This paper is dedicated to the 100th anniversary of establishing the State Statistical Office (an ancestor of today's Czech and Slovak statistical offices) in 1919. The paper first describes troubles with organization of the statistical service in Austria-Hungary where the Austrian and Hungarian parts of the monarchy had separate statistical services with different leaderships. In addition, separate land statistical offices with limited competencies operated in the lands of Cisleithanian. The paper also deals with preparations of the framework established by the Statistical Act, adopted in Czechoslovakia in January 1919, depicts lengthy negotiations concerning specifics of this law throughout the year 1919 and points out gradual development of the work of the State Statistical Office over 1919-1921.
\end{abstract}

\section{Key words}

Statistical State Council, State Statistical Office, Dobroslav Krejčí, Karel Engliš, František Weyr

\section{JEL classification}

B16, B23, N33

\section{Introduction}

Unlike other scientific disciplines, the history of statistics in our country is still inadequately elaborated. The authors of this paper gradually try to contribute to improving this state by partial papers about the development of statistics in the 19th and 20th century; see e.g. Závodský and Simpach $(2016,2017,2018)$, Kodera et al. (2015). This contribution is dedicated to the 100th anniversary of the establishment of the State Statistical Office in 1919, the direct predecessor of today's Czech Statistical Office and the Statistical Office of the Slovak Republic. Many authors have already dealt with this issue, often on the occasion of round anniversaries $-\mathrm{e}$. g. Podzimek (1979), Závodský and Šimpach (2019). In our paper, which is based on the original sources, we are trying to bring a somewhat new perspective on the events hundred years ago.

\section{State and land statistics of Austria-Hungary}

The State Statistical Service of the new Czechoslovak State was organized on the basis of experience (both positive and negative) with statistics in the Austro-Hungarian Empire. The organizational structure of official statistics in the Habsburg monarchy was rather complicated. Austria and Hungary had their own, totally independent statistical service, organized differently in many ways. In the Austrian part of the monarchy, the I. r. Central Statistical Commission (K. k. statistische Zentralkommission), incorporated under the Department of Religious Affairs and Education, was the representative of state statistics. However, the state statistics were largely decentralized - most Austrian ministries established their own statistical bureaus or offices. The most significant was the Ministry of Commerce, which had competencies in foreign trade and trade statistics within the Hungarian part of the monarchy, social statistics and partly also industry and transport statistics. 
The individual countries of Cisleithania had some limited autonomy. Statistics of various provincial affairs (elections, medical and charity institutes, public works, etc.) were initially managed by various provincial officials. Later, specialized provincial statistical offices were established (Bohemia in 1897, Moravia in 1899, Silesia in 1907), which also took into account their agriculture statistics in particular countries. The Land Statistical Offices worked independently of the Vienna Central Statistical Commission and jealously guarded their small competencies. Their activities were partly coordinated by the Conference on Land Statistics (Konferenz für Landesstatistik). They met alternately in various countries of the region of Cisleithania and published statistical yearbooks of the provincial governments.

In the Hungarian part of the monarchy, the statistical service was centralized to the Hungarian Royal Central Statistical Office (Magyar Királyi Központi Statisztikai Hivatal), headquartered in Budapest, subordinate to the Hungarian Ministry of Commerce. The only territory in Hungary, having some autonomy - Croatia-Slavonia Kingdom ${ }^{1}$, had its own statistical office in Zagreb. With some exceptions (e. g. external trade statistics), this autonomous authority carried out all statistical surveys on the territory of Croatia-Slavonia alone, in the case of all-Hungarian actions according to the instructions of the statistical office in Budapest.

The conditions of work of the Hungarian Statistical Office were codified in 1897 by a special law $^{2}$. A detailed survey plan was submitted to the Hungarian Parliament for approval by the Minister of Commerce. Citizens and legal entities were then obliged to provide proper information for such approved surveys. A penalty for failure to fulfil obligations could be the identification of the necessary data at the expense of the culprit or fine. Interesting was the legal obligation of village teachers to work as enumerators in censuses and education surveys. The law also ensured the protection of individual data, moreover, it explicitly forbade, within the framework of statistical surveys, to ascertain total incomes or total assets of natural persons and also certain facts from the totally private life of individuals.

The Czechoslovak State Statistical Office followed up the activities (and also personnel staffing) of the Land Statistical Office in Prague, which had a relatively extensive activity within its limited competencies and resources. It consisted of Land Statistical Committee as_an advisory body and quorum body, and Land Statistical Bureau as an executive body. The head of the office was since year 1905 Dobroslav Krejčí ${ }^{3}$ who was employed here since its foundation. He managed the Office for whole 14 years only as Deputy Chief, the position of the head of the office was not occupied in order to avoid a dispute with representatives of the German minority in Bohemia, who demanded the German management of the office. Consensus was not found in this way, many German districts and municipalities in Bohemia refused to provide the required data.

A permanent problem for the work of the provincial statistical authorities was the fact that no reporting duty was enacted in any area of their activity. It was set only by special legal norms imposed in the monarchy in four cases. These included the Population census, the Census of agricultural and trade, foreign trade statistics, and the "between-trade" statistics (trade between the Austrian and Hungarian parts of the monarchy). However, the Central Statistical Commission (with no branches outside Vienna) and other Viennese authorities could carry out their surveys in individual countries with the help of governorship and district governors, whose extensive powers guaranteed that respondents would not refuse to provide the required data. On the other hand, the authority of the Landtag in Bohemia and its executive body - the Provincial Committee, which could be asked for help by the country's statisticians - was small.

\footnotetext{
${ }^{1}$ It is part of the territory of today's Croatia.

${ }^{2}$ Here we take the information from publication of former director of the Hungarian Statistical Office, Buday (1915).

${ }^{3}$ Dobroslav Krejči $(1869$ - 1936) graduated from the Faculty of Law of the Czech University in Prague in 1891, then worked as a junior lawyer.
} 
Landtag was since year 1908 basically blocked by obstructions of German Members of Parliament. It was finally in summer 1913 together with Provincial Committee dismissed by imperial patents and has not renewed its activities by the end of Austria-Hungarian empire.

\section{The path to the Czecho-Slovak statistical law}

In Moravia, the Land Statistical Office developed less activity. In addition to finances and a deeper interest of provincial politicians, it lacked both qualified and enthusiastic figures, such as D. Krejčí and his colleagues in Prague. The hope of change for better appeared in June 1913, when Karel Engliš was elected to the Moravian Landtag. He was a professor of National Economy and Statistics at the Czech Technical University in Brno. Figure 1 displays Dobroslav Krejčí as well as Karel Engliš, the latter being then as the first rector of Masaryk University $(1919-1920)$.

Figure 1: Dobroslav Krejčí (on the left) and Karel Engliš (on the right)
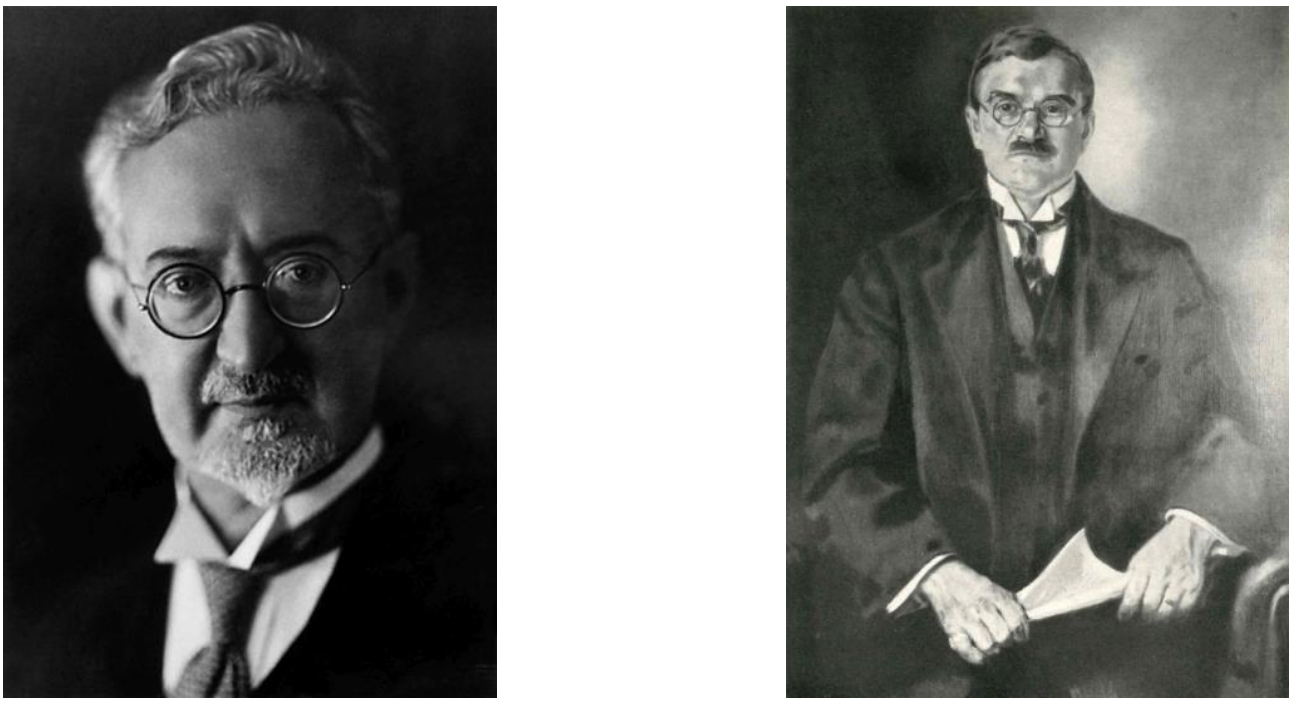

Source: Wikipedia (cit. 2019-01-15), Československý statistický věstník (1930, vol. 11, p. 494-a).

On the 3 February 1914 Engliš drafted a statistical law for Moravia, which obliges to municipalities and district road committees to provide information to the Land Statistical Office for surveys, which were approved by the Provincial Committee. As a sanction for failure to provide statistical data, the necessary data were gathered at the expense of the offending institution $(\S 3)$. Other 41 Members of the Landtag added their signatures to the proposal.

Engliš's proposals were approved with minor changes by two Landtag committees. On 28 February it passed smoothly in the final reading in the Moravian Landtag. After the signature of the emperor and the Austrian ministers, it was published on 18 December 1914 as Act No. 92/1914 in the Moravian Land Code of Law. For the first time, a general (abstract) reporting duty has been enacted in our country. Ironically, the law came into force when the Land Statistical Office in Brno actually ceased its activities - because many of its workers were called into the army due to the outbreak of War. Engliš's detailed draft of the new statute of the Land Statistical Office, which was supposed to extend it and improve its work, had not been discussed by the Landtag because it was closed at the same time as the declaration of War and its activity was not renewed.

The Land Statistical Office in Bohemia continued to a limited extent in its work during World War I. It focused mainly on statistics on agriculture and food production, in which was supported by the Vienna Ministry of Agriculture and the Prague governorship. The problems of the wartime economy and, in particular, the sharply deteriorating supply to the military, the 
population raised growing interest in the results of economic statistics across the monarchy. The situation also prompted a discussion in professional circles about the need to reorganize statistical services in the Austrian part of the monarchy.

Vienna Professor of national economy and major representative of the Central Statistical Commission Karl Přibram ${ }^{4}$ published in monthly journal Statistische Monatschrift an article Die amtliche Statistik Österreichs am Scheidewege (Austrian official statistics at the crossroads). He criticized the unsatisfactory status of the statistical service in Cisleithania (Pribram, 1915). He proposed in the article, according to the example of the organization of Hungarian official statistics in the Austrian part of the monarchy, to merge the statistical services of the individual ministries with the Central Statistical Commission into one office and to subordinate all provincial and municipal statistical offices.

In response to the call for discussion at the end of Přibram's treatise, D. Krejčí responded by the Czech article in Obzor národohospodárský and the more extensive article published in Statistische Monatschrift under the same name as Přibram's article (Krejčí, 1916). Krejčí agreed with Prribram's opinion on the need to enact a general reporting obligation. He published also his own specific proposal for solution - experts should prepare a brief and clear "statistical law" as soon as possible, which could be quickly issued as an imperial order at the time of the parliament's conclusion.

Krejčí, however, argued with Přibram's proposal for consistent centralization of all statistical services in the Austrian part of the monarchy. He proposed to solve the current unsatisfactory situation by coordinating of work of the state and self-governing statistical offices according to a unified plan of all statistical actions. On the contrary, they would gain a greater share of the land (or newly established regional) statistical offices, which are better acquainted with the specifics of their countries, closer to data sources and thus have better conditions for successful data collection and control. The polemic no longer continued. It was clear that the future reorganization of the statistical service in the monarchy would necessarily depend on the reform of the entire government.

Already before 28 October 1918 D. Krejčí prepared the first version of the new state statistics organization act, which he presented after the coup in the economic-statistical committee of the National Committee. This committee, however, ceased its activities soon. The National Committee was extended to the Revolutionary National Assembly (RNA) on 14 November. It was the unvoted supreme representative body of the new state, who worked until the spring of 1920. It was seated in the building of the former Bohemian Landtag in Sněmovní Street, where the Chamber of Deputies of the Parliament of the Czech Republic is today. Already on 14 November was approved the provisional Constitution and appointed the government headed by Karel Kramár. On 22 November, Krejčí handed him his law proposal with the explanatory report (Krejčí, 1919, pp. 4-5). Those interested will find the meeting room of the Revolutionary National Assembly visualized in Figure 2.

Although the government and the Revolutionary National Assembly had to deal with a number of urgent and fundamental problems of the new state, Krejčí tirelessly advocated the speedy adoption of the State Statistics Act. Already four days later, he found Member of the RNA Engliš and gave him his proposals. Engliš (Member of Parliament for State Democracy) in agreement with Prime Minister Kramár̆, submitted the act as his own parliamentary proposal. However, Krejčí significantly condensed and simplified Engliš's proposal to increase the chances of swift adoption of the law. At that time, the law could contain only the main principles of the organization of state statistics, because it has not been already decided about the system of central authorities of the Republic or about the division of the state into territorial units. Engliš's law proposal signed also by other 22 Members of Parliament, was with date

\footnotetext{
${ }^{4}$ Karl Přibram (1877 - 1973) was born in educated Jewish family in Prague and graduated here on Law Faculty of German University in 1900.
} 
1 December 1918 published together with brief justification as parliament press 147. Presidium of RNA assigned the act to the Social Political Committee for discussion.

Figure 2: The meeting room of the Revolutionary National Assembly at the Thun Palace in 1919

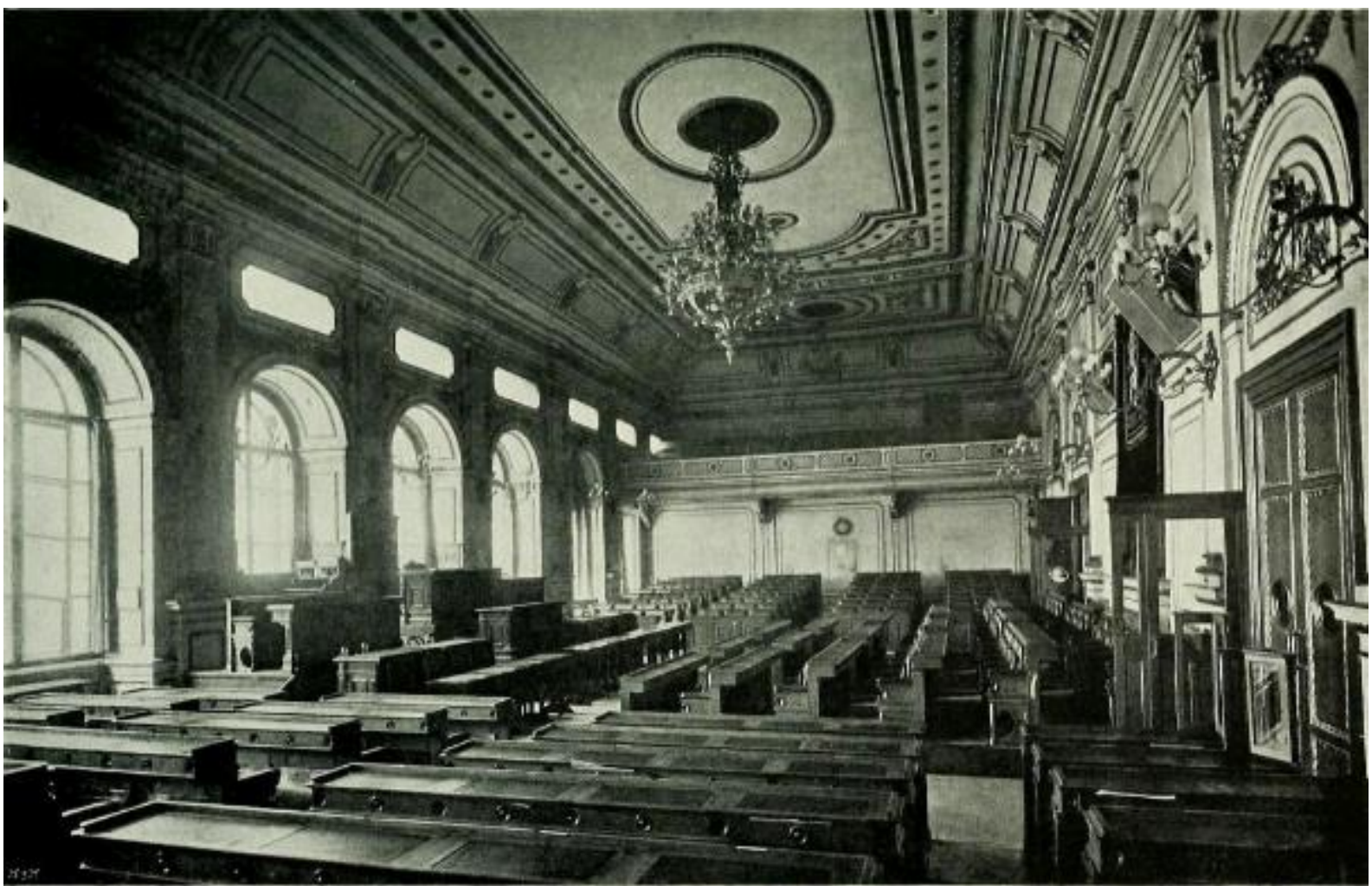

Source: appendix to L'assemblée nationale tchécoslovaque dans la première année de la république 1918 - 1919 published by the Praesidium of the National Assembly in Prague in 1919.

The text of the brief statistical law was slightly refined in a number of places by Engliš during December and early January, partly according to comments by D. Krejčí and his colleagues (J. Auerhan, J. Mráz). Social Political Committee of RNA discussed the act on 9 January. Engliš as a referent of the Committee at the hearing explained in detail and substantiated the principles of the new law. Czechoslovak state statistics need to be centralized into the State Statistical Council (SSC) as an advisory and quorum body and the State Statistical Office (SSO) as executive body. A head of SSC will be simultaneously a head of SSO and both bodies will be subordinated directly to the Prime Minister. Organization and a way of work of SSC and SSO later lays down by government orders as well as the structure of potential regional statistical bodies.

However, it is already clear in the law that the general reporting obligation for all surveys decided by the SSC should be clearly defined. Here it was possible to be inspired by statistical laws in Moravia, Hungary and some foreign states. The law must also include possible sanctions for non-compliance, as well as sufficient safeguards for the protection of individual data, which may not be disclosed or made available to another authority (namely the tax office). Land Statistical Bureau in Prague with its staff and inventory will be the basis for building a much larger SSO, the law does not mention the future fate of the Land Statistical Offices in Brno and Opava (see Figure 3). 
Figure 3: Law about organization of statistical service in the Collection of Acts and Decrees

Roxnik 1919.

\section{Sbirka zálionil a nařizeni

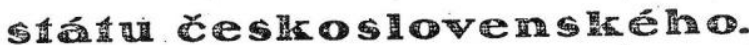

Ghsah: (Cis, 49-56) 49. Zákion o organisaci statistické služhy. - 50. Zakon, kterym вe zirizuje druhá ceská universita. - 51. Zákon o upotřebení části správnich eprebytkủ hromadných sirotě́ch pokladen. 59. Zákon, jímž se posḱytuji drahotni př́idavky altivním a pensionovaným uXitelûm veěejuých, obeoných

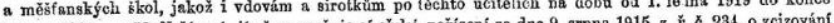

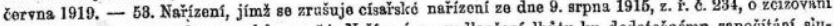
hospodarskych a lesnich pozembü. - 54. Narizeni o prodoużent lis

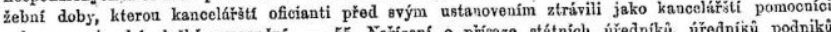

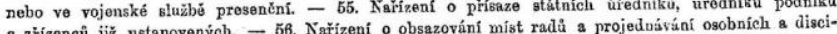

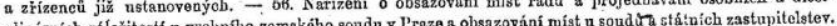

Čis. 49.

Zhblron ze due 28. ledna 1919 o organisaci statistické služby.

Na základě usnesení Národního shromáždění se nařizule:

$$
\text { \$1. }
$$

Služiou státni statistiky organísovati, řlditl i provádéti bude pro obvod celé Ceskosiovenské republiky

a) Statistická Rada Státní, jakožto orgán poradni a usıńšejicí,

b) Státni Ự̆ađ Statistický, jakožtơ orgán výkonný $\S 2$.

Statistická Rada Slátní a Státní Ửad Statistický jsou bezprostředuě podřizeny předsedovi ministerstva. V čele Statistické Rady Státní a zároveñ Statnosta jako pŕedseda.

$\S 3$.

Složeni, kompetence a způsob jodnanni Statistické Rady Státuí upravi se nayizcnim celého mistické Rady Statui upravi se narrizenim celeho ministerstva. Naúizenim ministerskéloo predsedy statistického, jakož i nižších orgánû statistických.

$$
\S 4 .
$$

Všechny statistické a jirdẻ úřady ve státe, státní, samosprávné, vojenské, církevni atd. jsor povinny podporovati Státni Uład Statistický pri plnění jeho úkolủ a đbáti jeho pokynů $\mathbf{v}$ mezích usnesení Statistické Rady Státn.

\section{§ 5}

Každý obyvatel státu, vyjímaje osoby poživací exteritoriality, jest povinen podavati sprâvine, ude po něm požadovati Státni Urad Statistický prímo nebo nepríimo jinými orgány neb úxady po. le usneseni Statistické Rady Státní.

Porıšcní této povinnosti se bude trestati politeckými úrady prrní stolice pokutou do $1000 \mathrm{~K}$ a při opětování nebo za přitě̌zulujicích .okolností ve

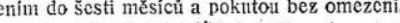
Státní Statistický Ư̌ad mûže mimo to provésti șctrêní přimo nebo neprímo na útraty provinilého.

\section{$\S 6$.}

Ustanoveni § 5. platí též pro všechny veřejné místní i zájmové svazky ve státé, jakož i pro spolky, družstva, a vydèlečne společnosti všeho druluu. Za splṇenti jejich statistické povinnosti zodpovédni jsoy osobné ti, kdož po zákonn jsou

\section{$\S 7$}

Uveřejňovánim statistických dat nesmí býti einnèní individuálních statistických dat Státním predpoklảdá schválení Statistické Rady Státní.

Neuveřciněné individuấhi statistické výkazy nesmí býti ani $\mathrm{k}$ nahlédnuití přenechány žádnému jinému ứadu, zvlašté ne uraadúm bernum. Individitalních statisticksch ve a

Souk pro uktickéto mo materialu za podmintek

11

$$
\S 8 .
$$

Vśichni, jichž prostłednictvím se statistická data sbiraij, zpracovávaij! neb uverejnúuji, jsou povinní zachovávati o všech věcech prì statistickém setření zijšténých, poktld se dotýkaji pomerú soukrónyých, přisnou mičenlivost vũči každému, také vưđi jiným nežli statistickým û̉ađüm, zvláště bernin

Portıšeni této povinnosti, jakož i každé zneıžití zpráv a údajû, získaných pro účcly statistické, se trestá bez újmy prýipadné soukromé náhrady skody řádnými trestiúmi soudy pokutou do $10.000 \mathrm{~K}$ nebo vězením do dvou let, po prvê jako přestupck, při opětování neebo za přitěžulijících cholností jako prečin.

$$
\text { § } 9 .
$$

„Zemská śtatistická kanceláł král. Ceskêho v Praze“ bếfe se se vším personálcm I zarîizením a se všemi svỹmi pravy l zâvazky do služeb statnich a povêruje se tholy Státn ho Oradu Statistického. „Zemská Statistická komise král. Ceského" se zrušuje.

$$
\S 10 \text {. }
$$

Zálion tento nabyvá ấinnosti dnem vyhlášky. Provedení Jeho se ukládá předsedovi ministerstva.

$$
\text { T. G. Masaryk v. r. }
$$

Svehla v. r., v zast. min. předsedy.

Source: Sbírka zákonů a nařízení státu československého (1919, pp. 59-60). 
Social Political Committee passed the act without any objection (i.e., a press release 147 with minor changes made and justified by Engliš) and recommended the plenary approval of the act. Definite draft of the act, with extensive Engliš's comments, was printed on 10 January 1919 and distributed to Members of RNA as a press 323. The discussion of the act was included as the fourth item of the 21 RNA meeting on 24 January, but then was moved to the next 22 meeting on 28 January.

Roughly around 5 P.M. a head of RNA F. Tomášek interrupted the discussion about the problematics of municipality election and called member Karl Engliš to present a report by the Social Political Committee on his draft law on the organization of the statistical service in the new state. In his speech, Engliš briefly and concisely clarified the principles of the proposed law and the need for its rapid adoption. A more detailed organization cannot be enacted at the moment,it will be later defined by the government order. More detailed information was available to Members in the report of the Social Political Committee (press 323).

The present (more than two hundred of the then 256 deputies) heard Engliš's speech, with no comments, so that the vote was immediately taken. At the call of the head of the RNA, the Members of Parliament who agreed stand up and he proclaimed that it was the majority. (It was voted four times, always on several follow-up paragraphs.) Immediately thereafter, the head asked "gentlemen" (actually there were also 8 women in RNA), to stand up if they agree with the wording of the law in the second (last) reading. Again, he stated the majority and thus the adoption of the law5.

The law was signed by the President of the Republic T. G. Masaryk on behalf of Minister of Interior Švehla and the Prime Minister Kramár. The Act was published in 8-days period on 5 February 1919 in the Collection of Laws and Regulations (Part XI / 1919) as Act No. 49 of 28 January 1919 Coll. On the organization of the statistical service. This came into effect.

\section{The beginnings of activities of the State Statistical Office}

The approved Act on the state statistical service supposed the publication of the statutes of the Statistical State Council and State Statistics Office in the form of a government regulation and the appointment of a joint chairman of both bodies (by the President of the Republic on a proposal of the Prime Minister). In this sense, the law has not been implemented for 10 months.

D. Krejčí with K. Engliš already in early February prepared the proposal of statutes of SSC and SSO, but the office of the Prime Minister decided to postpone the establishment of both bodies until approval of the forthcoming amendment of the Act no. 49. The proposal for amendments to the law, prepared by the Ministry of Interior, expected a reduction of autonomy of SSO, his subordination to the Ministry of Interior and some other changes. The draft amendment was finally withdrawn, and Act no. 49/1919 Coll. was then applied throughout the First Republic, but progress in the organization of state statistics did not occur.

The impatient Krejčí constantly presented and urged his proposals. The long-term presence of the Prime Minister at the peace talks in Paris, the riots at the borders, the conflicts with Hungary and the economic and social problems of the new state led to a constant postponement of the organization of the statistical service.

The only legal basis for activities of SSO was $\S 9$ of Act no. 49: "Land Statistical Office of Bohemian Kingdom in Prague... is authorized with the tasks with State Statistical Office..." Despite this, "the father of Czechoslovak statistics" Krejčí and his co-workers were able to develop the activities of SSO at least to a limited extent. New staff were recruited gradually (during 1919, the staff increased from 34 to 220), one of the most significant were Robert Kollar, Jan Náhlovský and Antonín Boháč. The biggest problem was the lack of space. The

\footnotetext{
${ }^{5}$ Společná česko-slovenská digitální parlamentní knihovna - Národní shromáždění československé - stenoprotokoly.
} 
SSO worked only in a few modified rooms of a residential building in Šeříková Street at Malá Strana (Figure 4), which "inherited" from the Land Statistical Bureau.

The solution to the problem of non-compliance by the government did not improve even after the appointment of Vlastimil Tusar's new government. On 14 July 1919, disappointed Krejčí told him his resignation from the leadership of the SSO (he has not been officially appointed yet).

The resignation was not accepted and on 13 August he received a decree appointing him the chairman of the SSO. Because he was not also appointed as chairman of the SSC and as the department chief (both expected by Law no. 49), Krejčí understood this as hard, by anything unjustified humiliation of his person (see Krejčí, 1916, p. 16) ${ }^{6}$. He refused the appointment and insisted on his resignation. During number of months it has not been decided about the resignation, so the management of SSO was taken over by Jan Auerhan ${ }^{7}$.

Figure 4: The oldest seat of the State Statistical Office at Šeř́ková Street 4/618

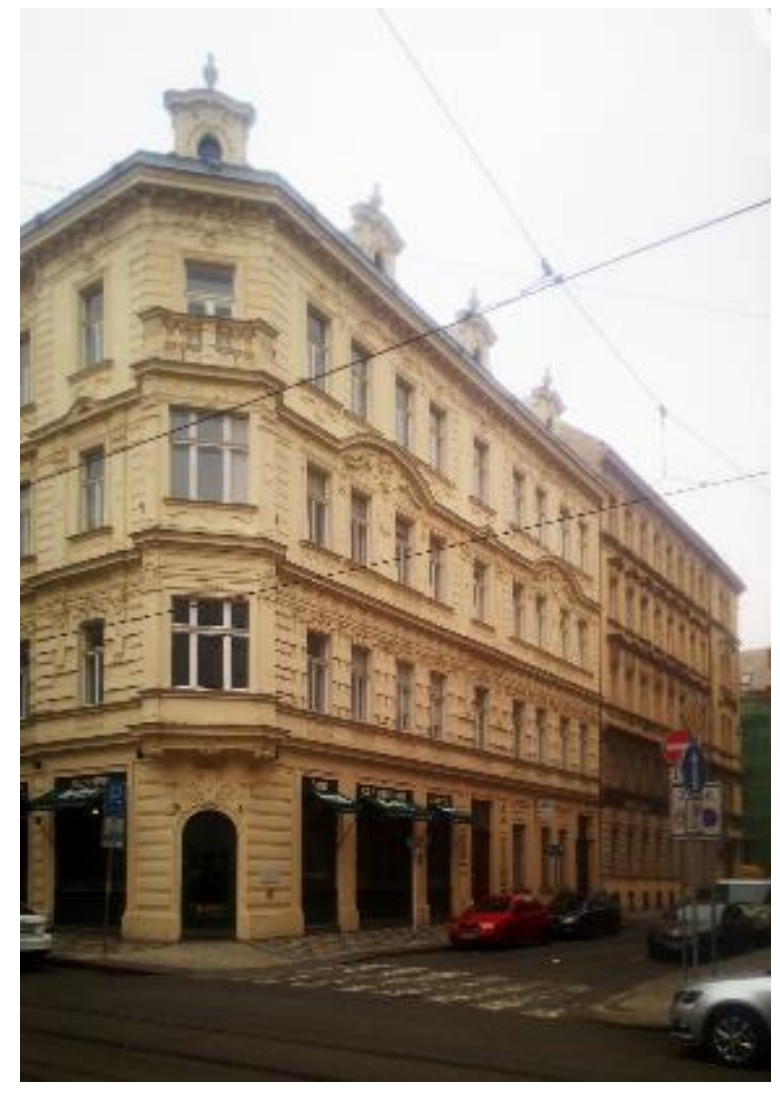

Source: V. Puci.

To determine the program and methods of statistical surveys was competent SSC by Law no. 49. Until it was established, a special law had to be adopted in urgent cases. On 18 September 1919 when RNA discussed government act on foreign trade statistics, approved by recommendation of its financial committee (a rapporteur was K. Engliš) in addition to the government bill, two resolutions calling on the government to "finally bring to life both the bodies of the state statistical service (SSC and SSO) by Act no. 49 Coll. with the highest speed", appointed their chairman, issued their statutes and for SSO "provide adequate space and adequate staff without delay". At the same time, RNA required the necessary autonomy for

\footnotetext{
${ }^{6}$ Recall that since 1905 Krejčí led the Land Statistical Bureau without being appointed its head.

${ }^{7}$ Jan Auerhan (1880 - 1942) studied law at the Czech University in Prague (graduation in 1904) and from 1906 he worked at the Land Statistical Bureau in Prague. In $1914-1918$ he served in the army.
} 
SSO in its activities ${ }^{8}$. The government's inaction on the fulfillment of Act no. 49 was also the subject of a question of deputy Rudolf Beran (and 21 others) on 14 November 9 .

On 28 November 1919 the government finally approved the statutes of SSC and SSO. both government regulations then came into force by publishing in the Collection of Laws and Orders on 12 December under no. 634 and 635. Members of the SSC were then appointed the representatives of ministries and other central offices, representatives of universities and technicians, local governments, trade unions and statistical experts, including leaders of SSO. Membership was for six years. Members worked in committees for different sectors of statistics. The SSC Plenary Meeting approved the SSO's annual work plan, also binding on natural and legal persons subject to reporting requirements. Only the government could abolish the SSC's resolution.

Statute of SSO established the conditions for the office's work according to the resolutions of SSC, his relationship with the Prime Minister, ministries, etc. At first, SSO consisted of a presidium and six departments, which gradually began its activities, most often in the autumn of 1919.

At the end of 1919, a critical lack of space for SSO's activities began to be addressed. On 26 October, a large building of the Deaf-Mute Institute in Smíchov (at that time Karlova Street, today's Holečkova Street 4/104) was seized for SSO, but it was only gradually released and partially adapted for the statistical office over the next two years. Executionary eviction of a charitable institution from its own building did not, however, contribute to the popularity of the statistical office. In addition, the building with large halls, but the lack of small offices, was not very suitable for SSO.

In February 1920 was finally the issue of the management of the two central statistical solved. On 3 February was a resignation of D. Krejčí accepted. On 19 February was inaugurated by his successor František Weyr, who was at that time professor of constitutional law at the Faculty of Law in Brno and at the same time its first dean ${ }^{10}$. Since he was unable to hold two positions in the state administration at the same time, he was appointed as SSC chairman and only entrusted as SSO chairman (he also received only a minor part of salary). Jan Auerhan was appointed as vice-chairman of SSO. Thanks to F. Weyr and K. Engliš for D. Krejčí was created as a job as a professor of statistics at the Faculty of Law in Brno ${ }^{11}$. A visualization of the seat of the State Statistical Office in 1920 - 1929 is available for study in Figure 5.

New chairman of SSO F. Weyr was quite different in character from tireless and pedantic D. Krejčí. As mentioned in his memoirs (Weyr, 2001) he led the SSO as the motto of the administration of ancient Rome minima non curat praetor ${ }^{12}$. In practice, this meant that he usually traveled to the statistical office from Brno every second week for less than three days. At that time, he chaired meetings of some SSC committees, held consultations with senior officials, decided on staffing and other important issues, and acted at the Prime Minister's office, possibly with some ministers. Managing the Office's routine issues was left to the head of each SSO department and other competent officials.

In the first months of 1920, work of Czechoslovakian state statistics was finally underway. On 24 March the first (extra ordinary) meeting of the SSC took place. There were 49 members delegated by central offices and other institutions according to the current statute of SSC,

\footnotetext{
${ }^{8}$ Společná česko-slovenská digitální parlamentní knihovna - Národní shromáždění československé - stenoprotokoly.

${ }^{9}$ Ibid, print 1884; answer of V. Tusar, print 2043.

${ }^{10}$ František Weyr $(1879-1951)$ also studied law at the Czech University in Prague (1904), then he worked among others at the Central Statistical Commission in Vienna (1905 - 1908) and at the Land Statistical Bureau in Prague (1909 - 1912). Since year 1912 he was a professor of law science at Czech Technical University in Brno. Since year 1919 he was a professor of Law faculty of Masaryk's university. In the years 1918 - 1920 he sat in RNA (for Czech State Democracy - like K. Engliš). As a member of the constitutional committee, he was one of the creators of the new constitution of Czechoslovakia.

${ }^{11}$ Krejčí had previously lectured (since 1909) as an honorary associate professor of agricultural statistics at Czech Technical University in Prague.

12 Praetor [a high official in Rome] does not care about insignificant issues.
} 
5 other members from renowned statisticians were chosen by the plenary of SSC. According to SSO vice-chairman J. Auerhan, SSC members approved the SSO Work Plan for 1920 and elected 14 SSC committees for various sector statistics. In the coming weeks, individual SSC committees have systematically started their work. The number of SSC members increased gradually. Further enlargement (up to 80) occurred after the amendment of the SSC Statute by the Government Act of 20 August 1920. Almost all prominent figures of statistics and related fields in Czechoslovakia were members of the SSC at that time. The number of SSO employees continued to increase, reaching 505 at the end of 1920 (295 women, none in more important positions). Figure 6 displays both prominent representatives of the State Statistical Office, F. Weyr and J. Auerhan.

Figure 5: Seat of the State Statistical Office in 1920 - 1929 (historical postcard)

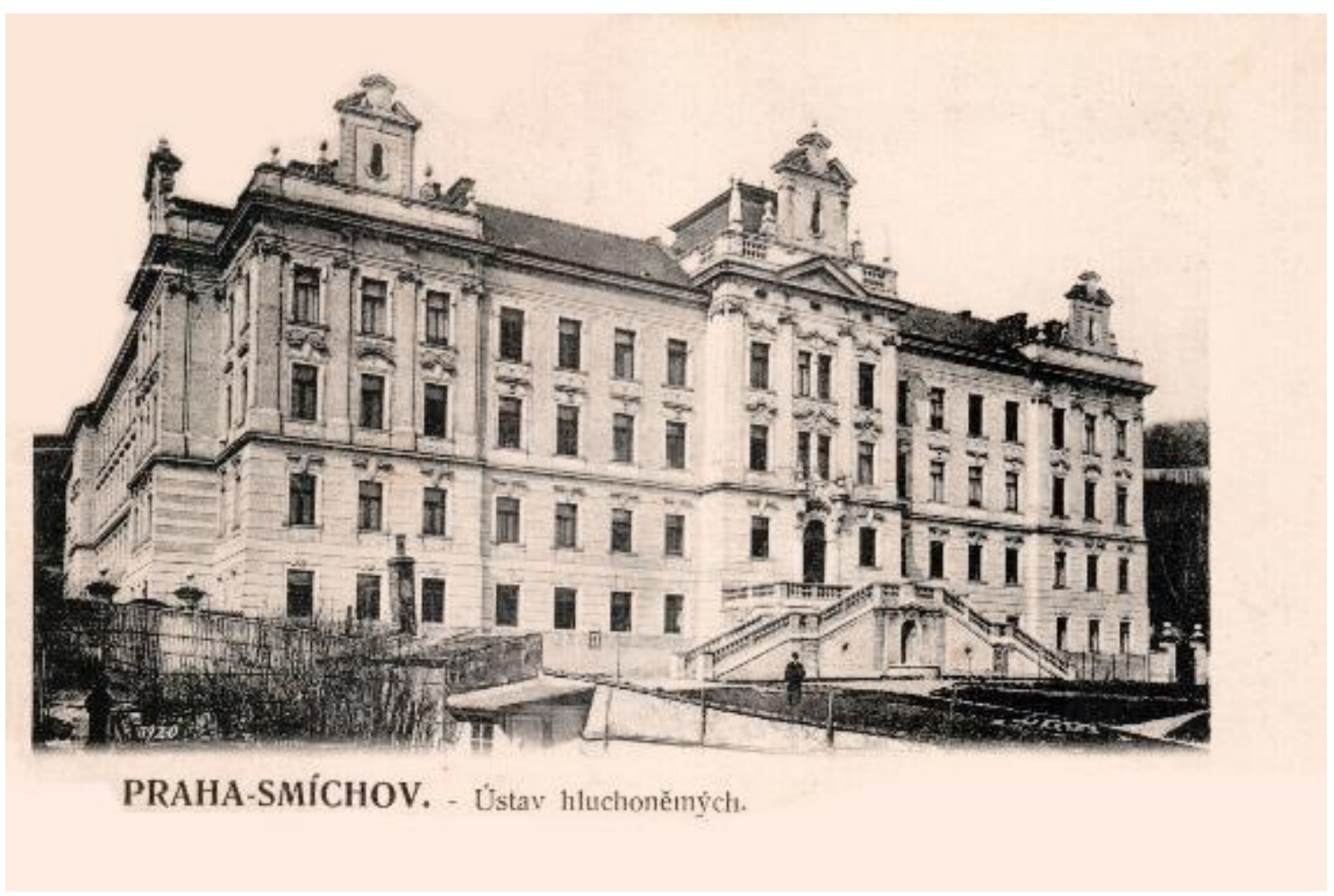

Source: The collection of postcards of P. Závodský.

Even in difficult conditions, the SSO managed to start publishing in 1920. The first edition of the professional statistical journal Československý statistický věstnik, the predecessor of today's quarterly Statistika journal. In June 1920 was issued Statistická príručka republiky Československé that brings on 106 pages 235 tables with available before- and also after-war data about territory of the new state. At the same time, individual workbooks of Zprávy Státního úradu statistického were published, imprinting various, often preliminary, results of statistical surveys. By the end of 1920, 22 news issues had been published ${ }^{13}$.

\footnotetext{
${ }^{13}$ Statistická př́ručka and Zprávy were published also in the French and German versions. In Čs. statistický věstník were published bilingually - Czech and French - full texts of statistical laws and government regulations, magazine content and some statistical tables.
} 
Figure 6: František Weyr (on the left) and Jan Auerhan (on the right)
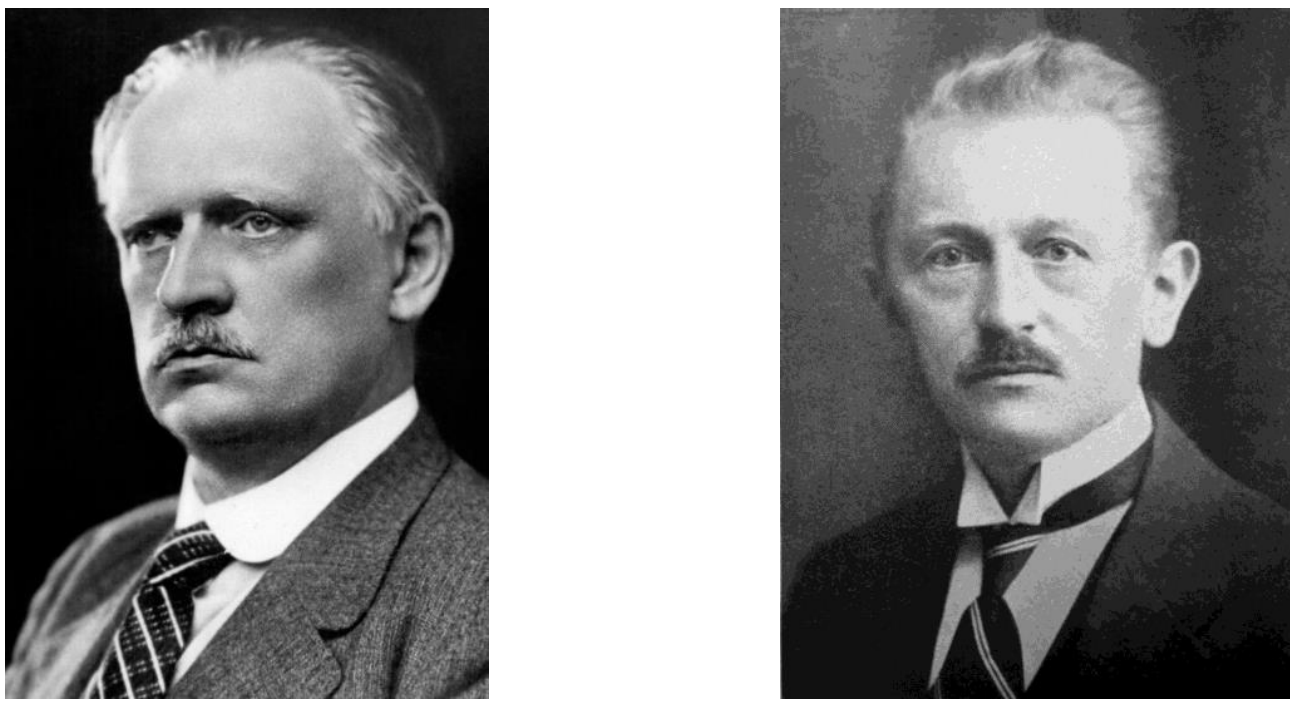

Source: Archive of Masaryk University in Brno, Sekanina (1927, p. 154).

\section{Conclusion}

The article summarizes basic information about the organization of state and autonomous statistical services in both parts of Austria-Hungary. It also focuses on the preparation of a framework law on the organization of the statistical service of the newly established Czechoslovak state. The rapid adoption of the law was also needed because Czechoslovakia had already by its first law decided on the provisional adoption of laws and regulations from the time of the monarchy, while the legislation of both parts of the monarchy differed significantly in the field of statistics. Great attention is paid to the legislative, organizational and personnel problems associated with the initial start-up of the work of the Statistical State Council and State Statistical Office in 1919 - 1920.

\section{Acknowledgements}

The paper was institutionally supported by the long-term research scheme of the Faculty of Informatics and Statistics at the University of Economics in Prague.

\section{References}

[1] Buday, L. V. 1915. Die Entwicklung der ungarischen amtlichen Statistik. In Allgemeines statistisches Archiv, vol. 9, pp. 197-212.

[2] Československý statistický věstník 1920 - 1922, vols. I - III.

[3] Kodera, J., Závodský, P., Šimpach, O. 2015. Jan Stocký, Southern Bohemia and Mathematical Methods in Economics. In Applications of Mathematics and Statistics in Economics - AMSE 2015. Prague : University of Economics in Prague, 2015. 11 pp.

[4] Krejčí, D. 1916. Die amtliche Statistik Österreichs am Scheidewege. Ein Beitrag zur Diskussion. In Statistische Monatsschrift, 1916, vol. 21, pp. 1-17.

[5] Krejčí, D. 1919. K historii vzniku Státního úřadu statistického. A Manuscript dated to 1919.

[6] Podzimek, J. 1979. Vývoj československé statistiky 1919-1945 v událostech a datech. Prague : Výzkumný ústav sociálně ekonomických informací, 1979. No ISBN.

[7] Přibram, K. 1915. Die amtliche Statistik Österreichs am Scheidewege. In Statistische Monatsschrift, 1915, vol. 20, pp. 483-494. 
[8] Sekanina, F. (ed.) 1927. Album representantů všech oborů veřejného života československého. Prague : Umělecké nakladatelství Josef Zeibrdlich, 1927. No ISBN.

[9] Sbírka zákonů a nařízení státu československého, vols. 1919 - 1920.

[10] Společná česko-slovenská digitální parlamentní knihovna - Národní shromáždění československé - stenoprotokoly. [cit. 2019-03-15] https://www.psp.cz/eknih/1918ns/ps/ stenprot/index.htm.

[11]Weyr, F. 2001. Paměti 2 - Za republiky (1918 - 1938). Brno : Atlantis, 2001. ISBN 80-7108-194-9.

[12]Závodský, P., Šimpach, O. 2019. A centenary of the State Statistical Office. In Statistika: Statistics \& Economy Journal, 2019, vol. 99, iss. 1, pp. 77-92.

[13]Závodský, P., Šimpach, O. 2016. The development of Provincial Statistical Office in Bohemia in historical context. In 10th International Days of Statistics and Economics. Slaný : Melandrium, 2016, pp. 2096-2106.

[14]Závodský, P., Šimpach, O. 2017. The development of statistics in the first decade of Czechoslovak Republic. In 11th International Days of Statistics and Economics. Slaný : Melandrium, 2017, pp. 1903-1913.

[15]Závodský, P., Šimpach, O. 2018. The origins of municipal statistics in Bohemian lands. In 12th International Days of Statistics and Economics. Slaný : Melandrium, 2018, pp. 2024-2033. 